\title{
The Consequences of a Forced Migration: The Return Home of WWII American Veterans
}

\author{
Isabel María García Conesa, Antonio Daniel Juan Rubio \\ Centro Universitario de la Defensa de San Javier, San Javier, Spain \\ Email: isabl.maria@hotmail.com,danirubio71@hotmail.com
}

Received 8 January 2016; accepted 11 March 2016; published 14 March 2016

Copyright (C) 2016 by authors and Scientific Research Publishing Inc.

This work is licensed under the Creative Commons Attribution International License (CC BY). http://creativecommons.org/licenses/by/4.0/

\section{(c) (i) Open Access}

\begin{abstract}
The end of the Second World War was a serious problem of rehabilitation, not only for the country but also for the huge mass of veterans returning home after the military conflict. And in order to avoid the unrest and social tension that followed the First World War, the US administration sled firstly by President Franklin D. Roosevelt and secondly by Harry Truman were commissioned to design a specific plan for rehabilitation and reintegration to civilian life of veterans. The Service Readjustment Act of 1944, informally known as the G. I. Bill, was an important law that provided a range of benefits for returning veterans of World War II. This law was passed in June 1944 in the United States, turning further into Public Law 78-346, being available to all veterans who served on active duty during the war years. Maybe it was the most representative and striking measure of the many related ones which were rushed by the US administration. Throughout this article we will focus primarily on the major consequences or repercussions that the adoption of the various measures undertaken had on American society in the late 40s, especially after the return home of the Second World War veterans.
\end{abstract}

\section{Keywords}

Rehabilitation, Migration, Social Measures, Reintegration, American Veterans

\section{Introduction}

American society has witnessed a long tradition of providing benefits to veterans. After the Civil War, for example, the largest unit within the federal budget expenditure was aimed at the benefits to veterans. But after the First World War, this current spending became a concern and an obsession for the administration. Because of 
this apprehension, the veterans of the Great War did not receive pensions which were at the same level as their predecessors.

Instead, they only obtained a return trip home and a small pay for their enlistment. These veterans eventually received compensation that was quite more substantial. This American tradition of appreciation towards the veterans was repeated after World War II again. And the way in which these benefits took shape was by means of the Servicemen Readjustment Act of 1944.

Popularly known as the G. I. Bill of Rights, or simply as the G. I. Bill, this bill guaranteed to the veterans who were returning from the battlefront educational opportunities, loan guarantees, employment service, unemployment benefits and some other lesser known benefits (Olson, 1973).

Although it could be said that the educational benefits had been considered as the most important impact of the G. I. Bill, there were other series of measures and actions which also had an enormous impact for both veterans and for the civil society which welcomed them in the second half of the forties.

In this period, between the late 1940s and the early 1950s, a great deal of the academic work related to this bill focused on its achievements and how well the law was working, at least apparently, as well as the benefits available to veterans at that time. The vast majority of these studies promoted the social work that this measure provided.

\section{The Return Home of WWII Veterans}

The end of the First World War and the ensuing depression not until fourteen years later that followed it were two factors which propelled the creation of the G. I. Bill. After the First World War, the veterans who had been injured were eligible to opt for federal benefits while those veterans who had served but were lucky enough not to be hurt or injured in the battlefield were only offered little more than a trip back home.

In 1924, veterans asked Congress to receive a bonus for their service time, especially after seeing the prosperity of those who had remained in the country during the war. The law enacted to put a remedy to this situation was the Adjusted Compensation Act of 1924. Although this bonus was agreed and passed on the House, it was never paid.

The culmination of these events was demonstrated in the two demonstrations scattered by the so-called "Bonus Expeditionary Force" in Washington DC in 1932 and 1933 respectively. Republican President Herbert Hoover crushed these incidents violently by sending federal troops over to the capital. This was the first time that federal troops were deployed against former US soldiers in the country.

Democratic President Franklin D. Roosevelt helped to rectify the second march of these veterans with the due payment to the veterans eligible for benefits. When writing about the incidents that took place in 1932, the American sociologist William W. Waller wrote the following: "No planning now is to plan disaster for the future" (Waller, 1944). Waller was undoubtedly referring to the fact that it was necessary to formulate a plan in order to avoid repeating the mistakes from the past.

The realization that there would soon be a new group of unemployed veterans returning home and the fact that they would require that the country take care of them came from the highest political level, specifically from the President Roosevelt and his wife Eleanor Roosevelt. Then, the latter said in 1942: "the veterans could create a dangerous pressure group in our midst” (Bennett, 1996).

The pressure that the President's wife spoke about was the fact that millions of men and women who served in the Armed Forces would become unemployed at the end of the war. So the president took action to combat this potential threat in an informal talk pronounced on June 28, 1943:

"Besides concentrating on the military victory, we are not neglecting the planning of the things to come. Among many other things, we are laying out plans to the return to civilian life of our brave men and women in the Armed Forces. I have assured them that the American people will not let them down when the war is won" (Roosevelt, 1943).

President Roosevelt continued detailing a pattern of six points of what he felt it was to be included in terms of benefits for the veterans returning home. This list included a payment of enlistment output, unemployment insurance benefits in education, allowance credit, and health care for the disabled in the war and pensions for disabled veterans.

There were a number of different factions involved in the drafting and approval of the G. I. Bill. The American Legion, for example, had the best wishes of veterans as its vanguard. This organization had been struggling 
to ensure that veterans were not forgotten at the end of the war and were left in misery as it had occurred after World War I.

By the fall of 1943, Congress had submitted 640 bills regarding veterans' affairs, but it did not act upon any of them. As a result, in November 1943, the American Legion had formed a committee, headed by former Illinois governor, John H. Stelle ${ }^{1}$, to draft a bill for readjustment of the veterans of the Second World War.

At the time when this committee was working on this bill, the Senate approved a bill to allocate five hundred dollars to veterans on pay compensation. The importance of this bill was simply the fact that it provided money for veterans when they were discharged. But before the House could pass the bill, it was postponed to the Second Session. Once more, it was another example of the lack of action undertaken by Congress.

In the House of Representatives, Congressman John Rankin of Mississippi, chairman of the "Legislation Committee of the Veterans of World War II", presented the G.I. Bill on 10 January 1944. Senator Bennett Champ Clark ${ }^{2}$ of Missouri, and one of the founders of the American Legion, introduced the companion bill in the Senate the next day. The promise of support for returning veterans that President Roosevelt had imagined less than six months ago finally appeared in Congress.

Both bills were approved in their respective chambers and had to go through a joint committee in order to standardize the projects that each House had approved. On the morning of June 9, 1944, the bill was unanimously approved after both the House of Representatives and the Senate had passed it on 12 and 13 June, respectively. A compromise agreement was reached between both chambers so as to get the bill passed.

Until finally, on June 22, 1944, the Servicemen Readjustment Act was finally signed into law, which was commonly known by the name of the G. I. Bill of Rights ${ }^{3}$. As its name suggests, the Servicemen Readjustment Act was primarily designed to help integrate the waves of veterans returning back home to American society after World War II. The main purpose of the G. I. Bill, therefore, was to ensure that soldiers returning from the battlefront have a smooth transition to civilian life so as to avoid the mistakes from the past.

During the war, the politicians from the two main political parties wanted to avoid the confusion of postwar upon the benefits given to veterans, who became a political target in the twenties and thirties. President Roosevelt wanted a post-war assistance program to help the transition to civilian life to this huge mass of veterans.

Veterans' organizations mobilized their support in Congress, which rejected Roosevelt's approach providing benefits only to veterans from the military service. Professor of political history at the University of Florida, Stephen R. Ortiz, said that his efforts "barricaded the VFW and American Legion as the two pillars of the pressure of the American veterans for decades" (Ortiz, 2010).

Republican congressman from Kansas, Harry W. Colmery ${ }^{4}$, a former national commander of the American Legion and former chairman of the Republican Party, was awarded the responsibility of writing the first draft of the G. I. Bill, passing onto the Senate the next day. According to a disclaimer by Glenn C. Altschuler (Altschuler, 2009) professor at Cornell University, ongressman Colmery wrote down his ideas on the devices of a desk or even on the napkins from the hotel where he was staying at.

US Senator Ernest W. McFarland ${ }^{5}$, a Democrat from Arizona, was also actively involved in the approval of the project and is known as one of the fathers of the G. I. Bill, as it is recognized by the historian James E. McMillan (Mcmillan, 2006) in his book.

Likewise, we could then consider the Republican congresswoman from Massachusetts, Edith N. Rogers, as the mother of the G. I. Bill since she helped write and co-sponsored the legislation that was pending in the House of Representatives. As it happened with Colmery, in the opinion of the historian Kathleen Frydl (Kathleen, 2009), her contribution to the drafting and approval of this law has been obscured by time.

\footnotetext{
${ }^{1}$ John Henry Stelle (1891-1962) was a U.S. political figure. He served as the $34^{\text {th }}$ Lieutenant Governor of Illinois for more than three and a half years in 1937-1940, and served as the $29^{\text {th }}$ Governor of Illinois for three months in 1940-1941 upon the death of Governor Henry Horner in October 1940. He served as National Commander of the American Legion from 1945 to 1946.

${ }^{2}$ Joel Bennett Clark (1890-1954), better known as Bennett Champ Clark, was a Democratic United States Senator from Missouri from 1933 until 1945, and was later a United States federal judge.

${ }^{3}$ House Resolution 540 was introduced on May 10, 1944 and later became into Public Law 78-346.

${ }^{4}$ The father of the G.I. Bill, Harry Walter Colmery, was born on Dec. 11, 1890, in Braddock, Pennsylvania. The legion and helping America's veterans became Colmery's passion. Aside from serving as National Commander, he held a number of executive board roles with The Legion over the years.

${ }^{5}$ Ernest William McFarland (1894-1984) was an American politician and is considered one of the "Fathers of the G. I. Bill". He is the only Arizonan to serve in the highest office in all three branches of Arizona government. He was a Democratic Senator from Arizona from 1941 to 1953 (Majority Leader from 1951 to 1953) before serving as the tenth Governor of Arizona from 1955 to 1959. Finally McFarland sat as Chief Justice on the Arizona Supreme Court in 1968.
} 
However, all these criticisms and reservations at the start were overcome by the pressure of public opinion. Finally, the Democratic President Franklin D. Roosevelt signed the G. I. Bill on 22 June 1944. The notoriety of this measure was clearly demonstrated in the statement by President Roosevelt after its approval:

"With the signing of this bill, it is almost completed a full program of special benefits to veterans of World War II. It provides an emphatic notoriety to the men and women of our Armed Forces so that they can feel that the American people will not disappoint them” (Roosevelt, 1949).

\section{The Social Consequences of the G. I. Bill in the American Society of the 40s}

There is a popular belief that the G. I. Bill treated all veterans alike. Unfortunately, this widespread belief does not seem entirely truthful. From now on, we will explain some of the provisions of this law that are not so well known, with special attention to the groups that it was intended to, especially the effects that this law had on minorities.

Although the G. I. Bill was popular for its seemingly egalitarian principles for all veterans alike, it was less egalitarian in its further application, in particular, the distribution of benefits to black veterans. Prior to the passage of the bill, Congressman John Rankin of Mississippi worked to ensure that the actual distribution and application of funds from the G. I. Bill were handled by the states. He argued that the application of this law was a state matter, not a federal one.

As Michael J. Bennet said: "The G. I. Bill was the first social legislation that did not notice the skin color in America” (Bennett, 1996). However, other studies show that this was not always as such. To this end, the purpose of this article is to explain whether this law really helped all veterans alike as it is popularly believed, though it is also true that it changed their role in society forever.

The G. I. Bill has a number of provisions in its final writing, some of which are not as well-known as the educational aspects. In fact, the final bill which was tabled in the House of Representatives contained fifteen chapters, dealing with a number of different aspects of life in the military discharged from service, from the right to housing to low-interest loans and assistance in education matters.

These chapters of the articles of the law include provisions such as the following: the benefit of the guarantee of part of a loan to buy a house or to start a business, employment services, unemployment services, amount of allowance benefit, disqualifications, money for hospitals, the administration of the law, and a number of legal issues which any law requires (Greenberg, 1997). An important aspect of the law is the definition of what qualifies as a veteran: "Anyone who served in the military on or after September 16, 1940 and before the end of this war, provided he or she has served for 90 days" (Simon, 2003).

The application of the G. I. Bill allowed many veterans to buy homes, to attend high school or college, opportunities that otherwise would have been economically impossible for them. But this bill, although it is described as primarily intended for all veterans, did not affect them all equally. For example, women had not even been seriously considered as eligible for these benefits.

The Veterans' Administration (VA) was the responsible for the implementation of this law. Unfortunately, in its first fifty years of existence, no records relating to women have remained. Without this sort of information there is no way to determine the real inability of women to thrive within the framework of the law.

Besides this fact, it was expected that women, as a general rule, were housewives and not much else in this era. In a questionnaire experiment carried out in the Air Force about the postwar ambitions of women in the military (Women's Army Corps, WAC) "73\% said that they preferred the marriage and the maintenance of the family home” (Higgins, 1944). So it is no surprising that women and their ambitions under the G. I. Bill were not discussed very often.

Women served in the army in all the different branches of service: the Women's Army Corps (WAC), the Army Nurse Corps, the Navy Nurse Corps, the Women's Marine Corps, and the Women Airforce Service Pilots (WASPS).

The majority of these women was granted the status of veterans and therefore had the ability to participate in the G. I. Bill like their male counterparts did, but not all them could. To give just one example, the Air Force pilot women were not granted the veteran status as their colleagues from other services were. As a result, these women lost the opportunity to improve through programs aimed for veterans.

An article written by Doria Higgins said that in 1940 "the percentage of women studying at university was 40\%” (Higgins, 1944). By 1947, that percentage had dropped to $29 \%$ due to the fact that the G. I. Bill typically 
benefited men, not women. It was obvious, then, that women were not finding their niche in the universities at that time.

Women may have struggled harder under the provisions of this law, but they were not the only group who experienced some form of discrimination. Hispanics, as a group, soon realized that the G. I. Bill was also discriminatory against them. A former army major and medical doctor named Hector P. Garcia started an organization in 1948 called the American G. I. Forum. This organization was formed because "they were denying benefits to Americans of Mexican ascendency and to other Hispanics throughout the entire country” (Himes, 1945).

One benefit which this group, logically, wanted to participate from was that of education. This can easily be surmised through the forum motto: "Education is our freedom and liberty should be the business of everyone".

As Hector Ramos said: "Hispanic veterans of World War II contributed to the political integrity of the country and to its social progress” (Ramos, 1998). The Hispanic veterans have not been, ultimately, the target of many studies. What we do know for certain is that this group of veterans found some difficulties under the G. I. Bill. Perhaps, further research on this social group will be completed in the future.

But there is another group whose struggle has been better documented and studied, African-American veterans, who experienced an uneven application of the law. Howard Johnson, in an article which came out in a magazine in 1947 said that "there were 1,554,000 black veterans returning from the war, with more than 700,000 black veterans in the southern states” (Johnson, 1947).

What we should always keep in mind is the fact that during the time in which the G. I. Bill was approved, both the military and the country were scavengers. Even the man who introduced the bill in the House of Representatives, Congressman Rankin, has sometimes been vilified for being a racist who almost let the law die in the committee because of their opinions.

Hilary Herbold wrote an interesting article full of the injustices and inequalities faced by African Americans at the hands of the Veterans Administration (VA). She reported that in 1947 in a southern state for which she would not provide the name, "the Veterans Administration employed 1700 veterans, of which only seven were African-Americans” (Herbold, 1994). And all this despite the fact that one third of all South veterans was African-American.

Added to this problem was the fact that the "separate but equal” principle was applied in hospitals dependent from the VA. As it was typical in the case of other services following the application of this principle, these hospitals were, in the best case, below the norm.

The VA obviously had some problems with the issue of race. However, they were not the only group of veterans who fought for this. As a general rule, cities had two separate messages, one for whites and another one for blacks. In the fifties, the national organizations changed their laws to include the provision that membership could not be based on race, religion or gender.

The misdistribution of benefits for black veterans resulted in two important but seemingly contradictory social effects in opinion of Sarah Turner (Turner, 2003). First, the unequal distribution of educational benefits exacerbated the socioeconomic differences between blacks and whites in the South. And secondly, for the few blacks who were able to take advantage of the law may have had the same consequences for their confidence in the government and citizen participation as to whites.

\section{The Consequences of G. I. Bill in the Education of Veterans}

The title II of the G. I. Bill provisions intended not only to achieve the broader objectives of the same, but also to revive the US economy which suffered a decline in the number of citizens with higher education.

On the other hand, the decade of economic depression which preceded the war created a generation of workers not only uneducated but also without any significant work experience. So, as the title II of the provisions states, "it would help in replenishing the human capital of the nation", capital that had been devastated by years of depression and war.

This law provided to any veteran with at least 90 days of service, the opportunity to follow one year of education at the government expense, with a maximum of four years available for those who had served longer. The government promised to pay the full tuition up to $\$ 500$, with an available additional stipend to cover living expenses.

These benefits were distributed directly to veterans instead of being distributed to universities or vocational 
schools, regardless of factors such as race. This fact prompted some analysts to describe the law as "a very egalitarian politics".

The veterans took definitely advantage of these benefits in overwhelming numbers, with more than 2.2 million veterans who wanted to pursue higher education by 5.6 million more who attended college or vocational education, according to the data provided by George K. Pratt.

In total, during the postwar period, it is estimated by the prestigious educator David Snedden, that the total number of veterans accounted for $49 \%$ of all students enrolled in vocational schools and universities, and 51\% of veterans took advantage of the education benefits in one way or another.

These overall figures significantly exceeded the projections of the federal government that had been calculated using data from a survey which showed that only between $8 \%$ and $12 \%$ of the veterans wanted to study full-time after the war.

Despite the high number of veterans who flooded the vocational training centers and universities across the country, there are a number of factors that make it difficult to discern the results of the G. I. Bill. To start with, it was demanded to the military recruitment offices that they provided evidence of the literacy and intelligence of those who tried to enter the armed forces and should deny it to those who did not meet the minimum requirements.

Because of this policy, the average soldier under 25 years entered the army with at least one more year of education than the average of the general population, according to the data provided by the professor of Sociology Charles Nam. So, the veterans were not singularly intelligent but they were also more likely to have the necessary academic training to immediately begin a university degree on their return. Therefore, it seems logical that they had significantly contributed to an increase in the enrollment rates, even without the G. I. Bill.

It also contributes to the difficulty of studying the results of this law the fact that a large part of those who served in the army were those who would have gone to college had not been called up for service. On the other hand, many soldiers had already enrolled in college before entering the Army. It is estimated, according to Karen Thomas, that about $14 \%$ in the Army and 6\% in the Navy were enrolled in college studies.

Finally, another factor to consider is that the G. I. Bill came at a time when there was already a strong increasing trend in the composition of formal education received by the male population in the country. In fact, the estimates by the "National Center for Education Statistics" show that the proportion of the US population that had completed at least four years of college education rose from $2.7 \%$ in 1910 to $4.6 \%$ in 1940.

It is very likely that, even when it had never been fought the Second World War and that the G. I. Bill had never been approved, higher education in the United States would have continued to see an increase in the enrollments with the already existing social trend.

Several studies approved after the adoption of the law have attempted to discern about what the effect of the G. I. Bill was. Different econometric studies have attempted to estimate the random effects of the law establishing comparisons between the data and studies of the Veterans Adjustment Act of 1952, which provided similar educational benefits to veterans of the Korean War.

A study carried out by the "National Bureau of Economic Research" found that the G. I. Bill probably increased the rate of college completion for veterans between $4 \%$ and $10 \%$. Given the low rates of college completion at that time, the study concluded that the service in time of war increased the rates of college completion about 50\%" (Bound \& Turner, 2002) due to the bill.

A similar study found that $75 \%$ of men who completed their first year at university during the years in which the benefits of the G. I. Bill were in force did so as a direct result of the law. Inevitably, this kind of change in the educational attainment of US veterans of course had a significant impact on society in general. The G. I. Bill drastically adjusted the American university system and the social perception regarding the university and the government.

However, an estimation of the social consequences of the law should be tempered by two important factors. First, the massive flood of returning veterans from the war would probably have created a large increase for attending college, with or without the law. And secondly, the creation of the middle class and other social changes commonly attributed to the G. I. Bill was almost certainly a product of many cultural factors that should not be attributed to a single piece of legislation.

The change in the perception of citizens about who should go to college was perhaps the biggest and most obvious consequence of the influx of veterans into the education system. Before the war, American universities 
were "typically rural, private, small and elitist for white Protestant" in the words of Willard Waller (Waller, 1944), with little to offer for the average citizen.

The veteran was, meanwhile, the quintessential American citizen, called to serve their country in times of war. The massive arrival of these American citizens to the universities created the perception that the university could be useful for more than just the privileged elite.

In addition, the egalitarian structure of the G. I. Bill began to challenge the traditional racial and ethnic divisions of higher education. Although its access was not the same as for white Protestants, blacks and Jews began to make greater progress in college, according to Hilary Herbold. Even Catholic centers began to admit a wider range of students to help accommodate the influx of veterans into the system. As Americans began to see the university as an institution with something to offer to ordinary citizens, they also began to see themselves as members of the college class.

A study examining the cultural representations of university and college, both before and after the war, focused specifically on this trend: "The same media images and the messages celebrating the common veteran man in the street and their influence on the change of aristocratic institutions could also be interpreted in the opposite direction" (Herbold, 1994).

This probably led to the perception that the university was a vehicle for the American working class in order to improve their social position and to seek a level of economic comfort that otherwise would not have been available for them.

This potential perceived as an upward social mobility strengthened the idea that the university was an institution that could benefit not only the elite and probably contributed to the sharp rise in college attendance. All this led to Paul Simon (Simon, 2003) to conclude that "the G. I. Bill helped transform the nation from a hierarchical society sharply divided by wealth and class to one where citizens aspired and reached middle-class status".

Although the massive increase of veterans attending college transformed the perception that society had of higher education in the United States, their presence also caused a change in the nature of the courses which these institutions offered.

A study by Edward Humes (Humes, 2006) at the end of the war of the soldiers returning home, found that $82 \%$ of them sought university studies with a high degree of practical application. Recent studies have confirmed that American universities responded to this call for practical training by creating programs specifically designed to meet the wishes of veterans.

The impact of this law on the perception of higher education was not limited only to American society. Recent studies have claimed that the G. I. Bill had a significant impact on the way in which veterans interacted with the government. Suzanne Mettler, professor of political science at Syracuse University, argues that this law finally helped foster a strong civil society, creating the perception among veterans that the government was willing to care for them.

Mettler argues that these positive perceptual influences made veterans participate in the civic and political life at a much higher rate. In fact, the study found that those who used the educational benefits participated in a 50\% increase in civic organizations and that they got involved in politics a 30\% more (Mettler, 2005).

To make matters worse, state governments were reluctant to increase their funds to accommodate more students. As a result, black institutions of higher education often rejected around 55\% of applicants, while whites' centers were expanding rapidly to meet the increasing demand. And since the vast majority of African-American veterans, over $75 \%$ were native of southern states, only $12 \%$ were able to pursue a college education, as opposed to $28 \%$ of whites.

Besides the many immediate consequences of the G. I. Bill on American society, the law also left a lasting legacy of government involvement in the system of higher education in the United States forever in terms of great involvement or the number of scholarships awarded. This transformed a system of merit-based aid to one that focused on helping as needed.

\section{Conclusion}

The Service Readjustment Act of 1944 is a very important piece of legislation, as well as an important part of American culture. That law made it possible for a multitude of US veterans to receive a number of benefits that would have been impossible for them otherwise.

As it happened with a number of past events, there is a tendency to idealize the real achievements of the law. 
As a veteran of World War II said: “The G. I. Bill was the way in which America said thank you”.

The G. I. Bill has been revived on three occasions since the end of the 1944 original law in 1956. In each of these successive laws, there have been people who remained in the top of the original ideals. For some, the $G$. $I$. Bill allowed pursuing what they regarded as "the American dream", while for others this dream was postponed.

The Service Readjustment Act of 1944 was remarkable, especially for fulfilling its goal of helping veterans returning to civilian life. In turn, it also contributed to the social consequences the implementation of this measure had on American society in the late forties.

Although the whole volumes could be written on the legacy of the G. I. Bill on the policy of the federal government of the United States and the social effects thereof, it should be enough to say for now that the benefits provided by it opened the gate to the final government involvement in some of the measures implemented as higher education or tax benefits.

So this comprehensive review of the legislation and quantitative analysis of its aftermath have shown us the true implications of the implementation of this measure to American society in general, and particularly the veterans themselves.

\section{References}

Altschuler, G. C. (2009). The G.I. Bill: A New Deal for Veterans. New York: Oxford University Press.

Bennett. M. J. (1996). When Dreams Came True: The G.I. Bill and the Making of Modern America. Washington: Brasseys.

Bound, J., \& Turner, S. E. (2002). Going to War and Going to College: Did the World War II and the G.I. Bill Increase Educational Attainment for Returning Veterans? Journal of Labor Economics, 20, 784-815.

http://dx.doi.org/10.1086/342012

Greenberg, M. (1997). The G.I. Bill: The Law That Changed America. New York: Lickle Publishing.

Herbold, H. (1994). Never a Level Playing Field: Blacks and the GI Bill. The Journal of Blacks in Higher Education, 6 , 104-108. http://dx.doi.org/10.2307/2962479

Higgins, D. (1944). After the Army-What? Women in Uniform Ask. The Washington Post, 19 August 1944.

Himes, F. T. (1945). Helping the Veteran to Find His Place in Post-War America. The American City, 60, 75.

Humes, E. (2006). Over Here: How the G.I. Bill Transformed the American Dream. New York: Harcourt.

Johnson, H. (1947). The Negro Veteran Fights for Freedom. Political Affairs, 26, 429.

Kathleen, F. (2009). The G.I. Bill. Cambridge: Cambridge University Press.

Mcmillan, J. E. (2006). Ernest W. McFarland: A Biography. Tucson, AR: The University of Arizona Press.

Mettler, S. (2005). The Creation of the G.I. Bill of Rights of 1944: Melding Social and Participatory Citizenship Ideals. Journal of Policy History, 17, No. 4. http://dx.doi.org/10.1353/jph.2005.0022

Olson, K. (1973). The G.I. Bill and Higher Education. American Quarterly, 25, 596.

Ortiz, S. R. (2010). Beyond the Bonus March and the G.I. Bill. New York: New York University Press.

Ramos, H. A. (1998). American GI Forum. Houston: Arte Publico Press.

Roosevelt, F. D. (1949). Statement on Signing the G.I. Bill. 22 June 1949.

Roosevelt, F. D. (1943). On Progress of War and Plans for Peace. Fireside Chat, Franklin D. Roosevelt Presidential Library. Simon, P. (2003). A GI Bill for Today. Chronicle of Higher Education, 50, 16.

Turner, S. (2003). The Effects of the G.I. Bill and World War II on the Educational Outcomes of Black Americans. The Journal of Economics History, 63, 145.

Waller, W. (1944). The Veteran Comes Back. New York: Dryden. 